\title{
Mast cells distinguish eosinophilic esophagitis in pediatric patients
}

\author{
Elizete Aparecida LOMAZI ${ }^{1}$, Nelson Ary BRANDALISE², Maria de Fátima Pimenta Correa SERVIDONI ${ }^{1}$, \\ Silvia Regina CARDOSO ${ }^{1}$ and Luciana Rodrigues MEIRELLES ${ }^{3}$
}

\begin{abstract}
Background - Mast cells exert a substantial role in gastrointestinal allergic diseases. Therefore, it is reasonable to presume that mast cell may aid diagnosis in eosinophilic gastroenteropathy. Objective - To evaluate whether mast cell count in the esophageal epithelium can discriminate eosinophilic esophagitis, proton-pump inhibitor (PPI)-responsive eosinophilic esophagitis and gastroesophageal reflux esophagitis. Methods-Retrospectively we reviewed the files of 53 consecutive patients (age: 7.8 years; range: 8-14 years) with definitive diagnose established during clinical follow up in a universitary outpatient clinic as follow: eosinophilic esophagitis ( $\mathrm{N}=23)$, PPI-responsive eosinophilic esophagitis $(\mathrm{N}=15)$ and gastroesophageal reflux esophagitis $(\mathrm{N}=15)$. Eosinophil count in the esophageal epithelium in slides stained with $\mathrm{H}-\mathrm{E}$ was reviewed and immunohistochemistry for mast cell tryptase was performed. Results - Count of eosinophils/high-power field (HPF) higher than 15 were found in 14 out of 15 reflux esophagitis patients. The mean count of eosinophils/HPF was similar in eosinophilic esophagitis patients and in those with PPI-responsive eosinophilic esophagitis (42 and 39 eosinophils/HPF, respectively, $P=0.47)$. Values of mast cell tryptase (+) were higher in eosinophilic esophagitis [median: 25 mast cells/HPF; range (17-43)] and in PPI-responsive eosinophilic esophagitis patients [25 (16-32)], compared to reflux esophagitis [4 (2-14)], $P<0.001$. There was no difference between the mean count of mast cells/HPF in the esophageal epithelium of eosinophilic esophagitis patients and PPI-responsive eosinophilic esophagitis patients, respectively, 26 and 24 mast cells/HPF, $P=0.391$. Conclusion - Tryptase staining of mast cells differentiates eosinophilic esophagitis from reflux esophagitis.
\end{abstract}

HEADINGS - Esophageal diseases. Eosinophilic esophagitis. Peptic esophagitis. Mast cells. Immunohistochemistry.

\section{INTRODUCTION}

Eosinophilic esophagitis (EoE) is a chronic inflammatory disease of the esophagus that affects children and adults with the first patients described three decades ago. EoE was defined recently by international consensus as an immune-mediated disorder. It is characterized clinically by symptoms related to motor dysfunction of the esophagus and histologically by the presence of eosinophilic inflammatory infiltrate in the mucosa ${ }^{(14)}$.

Other conditions may show similar symptoms and increased number of eosinophils in the esophageal mucosa: reflux esophagitis (RE) due to gastroesophageal reflux, infectious diseases, chronic intestinal inflammatory disease, medication-induced esophagitis and neoplasms, requiring differential diagnosis ${ }^{(7)}$.

Eosinophilic and peptic esophagitis progress with a high eosinophil count in the esophageal mucosa and are the most common dubious differential diagnoses in clinical practice $e^{(2,14,20)}$. According to Liacouras, 15 or more eosinophils per high-power field (HPF) in one or more specimens obtained from any esophageal segment indicates eosinophilic esophagitis diagnosis ${ }^{(14)}$. Recently, a new condition, in which symptoms and eosinophilic infiltrate respond to proton-pump inhibitor (PPI) trial, was described in pediatric patients $^{(17)}$.
Patients with PPI-responsive eosinophilic esophagitis currently acounts for about $30 \%$ of patients with increased eosinophil count in the esophageal epithelium ${ }^{(3,5,23,24)}$. After identification of these patients, diagnostic protocols for eosinophilic esophagitis have indicated the need for PPI trial to rule out eosinophilic esophagitis responsive to PPI, before a definitive diagnosis of eosinophilic esophagitis is proposed ${ }^{(14)}$.

The pathophysiological interrelation between PPI-responsive eosinophilic esophagitis, RE and EoE is unknown and clinical and histopathological overlapping between them is not uncommon, justifying the search for laboratory methods that may contribute to differential diagnosis. Several studies have investigated the role of special staining to identify inflammatory mediators and eosinophil derived elements, aimed at increasing the predictive value of the differential diagnosis. Some reports have indicated that a higher count of mast cells in the esophageal mucosa may be a diagnostic marker for EoE and PPI-responsive eosinophilic esophagitis ${ }^{(1,4,10,18,19,22)}$.

The aim of this study was to confirm that the presence of mast cells in the esophageal epithelium of children, identified by immunohistochemistry for tryptase, may be associated with EoE and/or PPI-responsive eosinophilic esophagitis and can be useful in the differential diagnosis with RE.

Declared conflict of interest of all authors: none

Disclosure of funding: Auxílio pesquisa FAPESP 12/50416-6

${ }^{1}$ Departamento de Pediatria, Faculdade de Ciências Médicas, Universidade Estadual de Campinas, Campinas, SP, Brasil; ${ }^{2}$ Departamento de Cirurgia, Faculdade de Ciências Médicas, Universidade Estadual de Campinas, Campinas, SP, Brasil; ${ }^{3}$ Departamento de Patologia, Faculdade de Ciências Médicas, Universidade Estadual de Campinas, Campinas, SP, Brasil.

Correspondence: Elizete Aparecida Lomazi. Departamento de Pediatria. Rua Tessália Vieira de Camargo, 126. Cidade Universitária "Zeferino Vaz" Barão Geraldo - CEP: 13083-887 - Caixa

Postal 6109 - Campinas, SP, Brasil. E-mail: elizete.apl@gmail.com 


\section{METHODS}

Eligible children were selected from a cohort of patients referred to a universitary hospital for investigating symptoms suggesting esophagitis while they were followed by pediatric gastroenterologists.

Medical charts and esophageal biopsy samples of children up to 14 years of age, consecutively undergoing esophagogastroduodenoscopy (EGD), from January 2012 to August 2013 were reviewed. According our protocol, patients underwent to EGD for diagnostic purposes are followed until to diagnosis definition at the Hospital Outpatient Specilized Clinic. Additionally, and also by protocol, during our EGD diagnostic procedures, a total of four esophageal samples were biopsied (two from the mid/proximal esophagus and two from the distal esophagus).

Excluded were patients with a previous diagnosis of esophageal varices, inflammatory esophageal disease, caustic stenosis, esophageal atresia or those receiving corticosteroid treatment.

Included in the study were patients with a diagnosis of EoE, PPI-responsive eosinophilic esophagitis or RE. Clinical and endoscopic response to treatment with PPI were used to define diagnosis, so as inclusion criteria patients must have performed a second EGD after using PPI for 8 weeks. Following clinical and endoscopic outcome, patients were classified into three groups:

\section{Group 1. Eosinophilic Esophagitis}

Diagnosis based on clinical/endoscopic features, associated with the presence of at least 15 eosinophils per high-power field of highest magnification (x400) in the esophageal mucosa. Histologic control showed the persistence of $>15$ eosinophils/HPF after using PPI for 8 weeks ${ }^{(14)}$.

\section{Group 2. Gastroesophageal Reflux Esophagitis}

Diagnosis based on symptoms, endoscopic and histologic findings compatible with erosive esophagitis in the distal esophagus that responded clinically to 8 weeks of treatment with PPI, when a histologic control showed no sign of mucosal inflammation.

\section{Group 3. PPI-Responsive Eosinophilic Esophagitis}

Diagnosis based on clinical and endoscopy data with at least 15 eosinophils/HPF in the esophageal mucosa. Clinical improvement occured after 8 weeks of treatment with PPI, associated with a decreased eosinophil count $(\leq 5)$ in biopsies obtained by control endoscopy, and normal $\mathrm{pH}$ monitoring.

Data related to demographics, clinical features and clinicalendoscopic progression of these patients were obtained from their medical charts.

\section{Immunohistochemistry and mast cell count}

Formalin-fixed paraffin-embedded tissue blocks were masked and sectioned (5- $\mu \mathrm{m}$ thick). Slides were deparaffinized with xylene, steam-treated for antigen retrieval, incubated with a mouse antihuman mast cell tryptase primary antibody (Mouse monoclonal

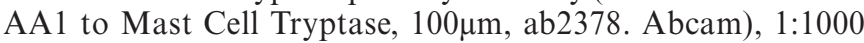
dilution), and incubated with a peroxidase-labeled anti-mouse polymer secondary antibody (Envision Dual Link; Dako), stained with diaminobenzidine chromogen (DAB; Innovex Biosciences, Richmond, CA), and then counterstained with Mayer hematoxylin. The mean mast cell density per HPF was determined by count of Tryptase-positive cells in five contiguous HPFs (field size $0.23 \mathrm{~mm}^{2}$ ) in the esophageal epithelial layer in areas with greatest density of mast cells. The highest mast cell count (in a single HPF) was also calculated.

\section{Eosinophil count}

Archived pathology slides were re-reviewed to determine eosinophil count. Hematoxylin-eosin stained slides were masked for EoE, PPI-responsive eosinophilic esophagitis or RE status. Peak eosinophil density (eosinophils/HPF) was determined after examination of 10 microscopy fields.

\section{Esophageal pH monitoring}

Studies had been performed accordingly described by Koda and co-workers ${ }^{(12)}$.

This project was approved by the Medical Research Ethics Committee of the university hospital. Authors were exempt from requesting a free written informed consent term, since this is a retrospective study. Number and date of approval were 1082/2011 and 02/13/2012, respectively.

\section{Statistical analysis}

Continuous variables were compared by the Mann-Whitney test. Calculations were performed using SPSS software for Windows, version 16.0 (Chicago, Illinois). A two-tailed $P$ value of 0.05 was considered statistically significant.

\section{RESULTS}

According to medical records of the Digestive Endoscopy Unit, 274 esophagogastroduodenoscopies were performed from January 2012 to August 2013. Reasons for performing the exam were: endoscopic treatment of esophageal varices $(\mathrm{N}=70)$, dilatation due to caustic esophagitis $(\mathrm{N}=34)$, normal exams $(\mathrm{N}=24)$, postoperative dilatation of esophageal atresia $(\mathrm{N}=18)$, peptic gastritis $(\mathrm{N}=16)$, foreign body removal unassociated with underlying esophageal disease $(\mathrm{N}=16)$, endoscopic diagnosis of reflux esophagitis $(\mathrm{N}=26)$, diagnosis of eosinophilic esophagitis $(\mathrm{N}=23)$, diagnosis of PPI-responsive eosinophilic esophagitis $(\mathrm{N}=15)$ and other diagnoses $(\mathrm{N}=32)$. From endoscopy records, patients were identified for reviewing their medical charts and archived tissue samples in the Division of Pathology. Included in the study were $23 / 23$ patients with eosinophilic esophagitis, $15 / 26$ patients with peptic esophagitis and $15 / 15$ patients with PPI-responsive eosinophilic esophagitis. Patients initially diagnosed with RE were excluded after failing to appear for repeat endoscopy that preclude definitive diagnosis. Clinical and endoscopic data of study patients are shown in Table 1 .

The distribution of levels of eosinophils and mast cells/HPF in patients with EoE, PPI-responsive eosinophilic esophagitis and RE, and their respective nonparametric test values (Mann-Whitney) are shown in Figure 1. Eosinophil count/HPF above 15 was found in 14 out of $15 \mathrm{RE}$ patients. The mean count of eosinophils/HPF was similar in patients with EoE (42 eosinophils/HPF) and PPIresponsive eosinophilic esophagitis (39 eosinophils/HPF) $(P=0.47)$. Levels of tryptase $(+)$ mast cells were higher in the esophageal epithelium of patients with EoE [median: 25 mast cells/HPF; range (17- 43)] and PPI-responsive eosinophilic esophagitis [25 (16-32)], compared to RE patients [4(2-14)], $P<0.001$. There was no difference between the mean count of mast cells/HPF in the esophageal epithelium of EoE patients compared to those in PPI-responsive eosinophilic esophagitis patients, 26 mast cells/HPF and 24 mast cells/HPF, respectively $P=0.391$. 
TABLE 1. Clinical and EGD characteristics of patients with a definitive diagnosis of EoE, PPI-responsive EoE or RE

\begin{tabular}{|c|c|c|c|}
\hline & EoE & PPI-responsive EoE & RE \\
\hline $\mathrm{N}(\%)$ & $23(43.4)$ & $15(28.3)$ & $15(28.3)$ \\
\hline Age at diagnosis $($ mean $\pm \mathrm{SD})$ & $8.4 \pm 2.83$ & $8.36 \pm 1.64$ & $7.48 \pm 1.88$ \\
\hline Previous EGD & 21 & 11 & 2 \\
\hline Previous discontinuous PPI therapy & 19 & 15 & 11 \\
\hline Duration (mean, months) & 11 & 18 & 7 \\
\hline Dysphagia & 14 & 10 & 4 \\
\hline Abdominal pain (epigastralgia) & 5 & 4 & 8 \\
\hline Vomiting & 2 & 3 & 3 \\
\hline Weight loss & 7 & 8 & 2 \\
\hline Rings & 5 & 4 & 2 \\
\hline Narrowing & 5 & 4 & 1 \\
\hline White exudates & 12 & 4 & 1 \\
\hline Erosive esophagitis & 2 & 3 & 6 \\
\hline Decreased vascularity & 2 & 1 & 2 \\
\hline
\end{tabular}

EGD: esophagogastroduodenoscopy; PPI-responsive EoE: Proton-Pump Inhibitor responsive Eosinophilic Esophagitis; RE: reflux esophagitis.

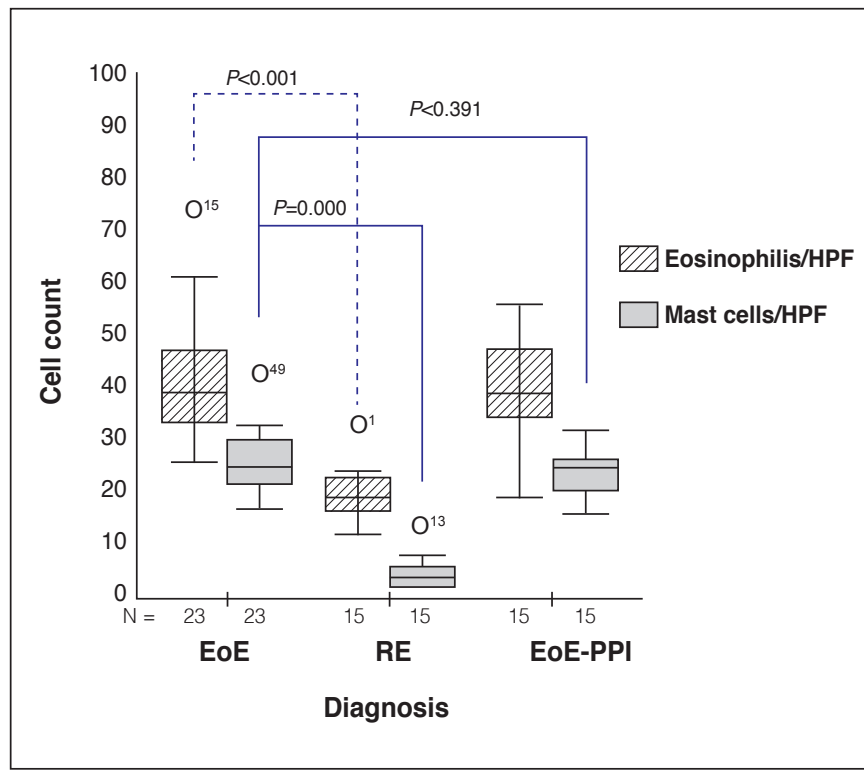

FIGURE 1. Graphic distribution of numbers of eosinophils and mast cells/HPF in patients with EoE, PPI-responsive EoE and RE, distributed in box-plot and respective nonparametric test $P$ values (Mann-Whitney). HPF: high-power field; EoE: eosinophilic esophagitis; RE: reflux esophagitis; PPI: proton-pump inhibitor.

In Figure 2, we exhibit photos of tissue samples stained by Hematoxylin-Eosin (A) technique and immunohistochemistry for mast cell tryptase, biopsied from EoE patients (B).

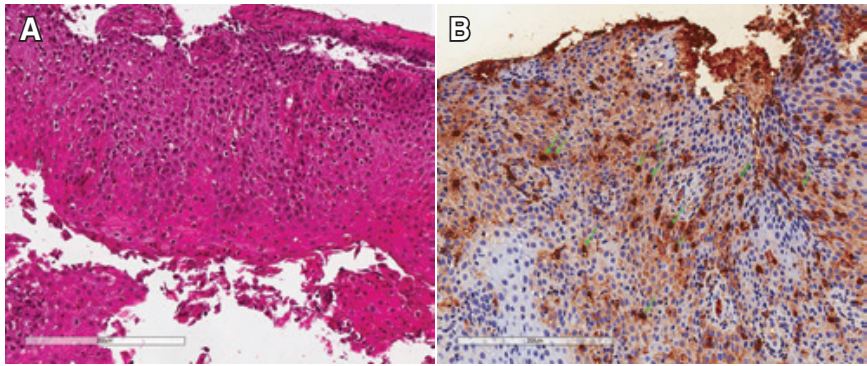

FIGURE 2. (A) Hematoxylin - eosin in histologic sample of patient with eosinophilic esophagitis (B) Staining for mast cell tryptase (arrows) in esophageal biopsy sample of patient with eosinophilic esophagitis.

Among the 15 patients diagnosed with PPI-responsive eosinophilic esophagitis, 14 children continue follow-up (median 21 months, minimum: 9 months, and maximum: 31 months), without clinical symptoms.

\section{DISCUSSION}

We retrospectively evaluated data from 53 children and adolescents seen in a tertiary specialized clinic and referred for performing EGD. Definitive diagnosis of eosinophilics or reflux esophagitis were set accordingly our regular protocol, that is based on data from a second endoscopy performed after an 8-week trial of PPI therapy.

Eosinophil count was higher in EoE when compared to RE and levels of tryptase-positive mast cells were similar in patients with EoE and PPI-responsive eosinophilic esophagitis and also higher than those found in RE patients. We concluded that immunohistochemistry for mast cell tryptase may strenghten reliability 
of the differential diagnosis between RE and EoE/PPI-responsive eosinophilic esophagitis, however, it failed to distinguish EoE from PPI-responsive eosinophilic esophagitis.

Present proportion of patients with esophageal eosinophilia who responded to a PPI trial was very similar to results found in studies published from 2009 to 2013 , including children $^{(3,23,24)}$. Retrospective studies confirmed that $40 \%$ to $70 \%$ of children and adults with esophageal eosinophilia responded to PPI. Differences in epidemiology, pharmacological protocols, and clinical/ pathological data used to define a positive response to PPI may explain these variations.

Our study may not be considered for epidemiology considerations on esophagitis in children, since we reviewed a selected group of children referred to a tertiary health care institution. Data from international studies on esophagitis in children ${ }^{(25,26)}$ and Brazilian case series $^{(6,28)}$ show that RE is significantly more common than eosinophilic esophagitis. In Brazil, EoE may be considered a rare disease $^{(6,28)}$. Our series, differently, shows a similar number of patients with EoE and RE, this is seen as a restrictive factor for epidemiology conclusions. Additionally, we have a great number of lost patients with RE suspicion diagnosis, since they did not come back for a conclusive second endoscopy. We can not explain such occurrence but we suppose they could get better after PPI trial and decided not to adhere to recommendations.

Kirsch et al. observed that mast cell count was greater in the esophageal epithelium of pediatric EoE patients, in comparison to GERD patients ${ }^{(10)}$. Those authors did not consider PPI-responsive eosinophilic esophagitis, defined and reported in the literature 1 year before their publication ${ }^{(17)}$. However, in the results, the authors described isolation of a subgroup of GERD patients whose eosinophil and mast cell count was higher than the remaining GERD patients. It was concluded that the subgroup had an allergic component. It is interesting to note that such subgroup without classification might correspond to patients currently classified as PPI-responsive eosinophilic esophagitis.

In the current study, patients with PPI-responsive eosinophilic esophagitis exhibit a significantly lower eosinophil count than EoE patients, despite a similar count of mast cells. These findings reproduce the pattern found in adults. Concerning the pathogenesis of PPI-responsive eosinophilic esophagitis, it has been hypothesized that a peptic and allergic hypersensitivity component is present. This fact has been interpreted as an indicative that PPI-responsive eosinophilic esophagitis and EoE represent different stages of a single nosologic entity ${ }^{(22)}$.

Eosinophils are not normally seen in healthy esophageal muco$\mathrm{sa}$, but as an evidence of esophageal inflammation ${ }^{(7)}$. In eosinophilic esophagitis, inflammation is due to a mixed-type immune-mediated reaction. In the late phase of allergic inflammatory reaction type I, circulating leukocytes are recruited and activated to the site of allergic reaction. This infiltrate includes lymphocytes and particularly eosinophils, which release inflammatory mediators after recruitment. Inflammatory mediators recruit lymphocytes Th2, which lead to recruitment of mast cells and eosinophils ${ }^{(9)}$.

Mast cells are effectors of gastrointestinal tract allergic diseases, such cells interact with antigenic nutrient epitopes and induce food allergies $^{(11)}$. The role of mast cells in eosinophilic esophagitis seems to be related to Th2 mechanism of immune response, triggered by exposure to food antigens. The cascade of inflammatory mediators is initially triggered by the release of interleukin-13 that stimulates cells of the esophageal epithelium to produce eotaxin-3, which later recruits eosinophils to the esophagus. When eosinophils are activated by eotaxin-3, degranulated eosinophils release "major basic protein", a mast cells activator. Activated mast cells produce interleukin-13 that stimulates recruitment and activation of eosinophilic infiltrate to the site of inflammation ${ }^{(21)}$. Genes associated with mast cell recruitment are upregulated in eosinophilic esophagitis and produce inflammatory mediators, that are implicated both in the migration of inflammatory cells into the site of aggression and in fibrosis generation ${ }^{(1)}$.

The first report on the predominance of mast cells in adult EoE patients was published in $2001^{(27)}$. Studies on pediatric patients were later described. A publication including 11 children, 1 to 18 years old with EoE and healthy controls identified an increased concentration of mast cells in the esophageal mucosa of patients ${ }^{(8)}$. Almost simultaneously, a study conducted in children quantified a significant difference between mast cells and eosinophils per histologic area, in $\mathrm{mm}^{2}$, as an effective instrument in the differential diagnosis between EoE and $\mathrm{RE}^{(10)}$. Further studies confirmed that the immunohistochemical method is reproducible for differential diagnosis ${ }^{(15,16)}$. In our study, the criteria for diagnostic classification was the differential aspect. The initial clinical-endoscopic impression was not presumed as definitive. In our point of view, systematization of follow-up has permitted a higher degree of certainty in the final diagnosis. Studies that classify patients by initial endoscopic and pathologic studies run the potential risk of misdiagnosis. This is the first pediatric study including patients with a diagnosis of PPI-responsive eosinophilic esophagitis, confirmed by therapeutic trial.

Although mast cell count did not permit a differential diagnosis between EoE and PPI-responsive eosinophilic esophagitis, there are still conditions in which the use of such stain can unequivocally distinguish one diagnosis from the other. Apparently, mast cell count does not suffer interference with the use of omeprazole, a commonly used over-the-counter drug in individuals with symptoms of esophagitis ${ }^{(13)}$. If the initial endoscopic study is performed near the time of omeprazole use, with an inconclusive endoscopic report and eosinophil count below 15 , mast cell count could be the differential element indicative of PPI-responsive eosinophilic esophagitis.

Finally, it seems error prone that finding 14 cells/HPF would define RE, while 15 defined EoE. Symptoms of both conditions are similarly manifested as discomfort caused by esophageal inflammatory process, regardless of the pathophysiology of inflammation. For pediatric patients, identifying the differential diagnosis by mast cell count can mean the difference between difficult management with corticosteroid treatment or food elimination from the diet and a regimen of PPI, what can make a huge difference.

Future studies may validate current results and tryptase-positive mast cell count may be included in clinical trial protocols to facilitate the diagnosis of EoE.

\section{CONCLUSION}

Immunohistochemical staining of mast cell tryptase may increase reliability and diagnostic accuracy in patients with eosonophilic esophagitis.

This work was supported by grants from the Research Support Foundation of the State of São Paulo/FAPESP, Financial support for Regular Research, Project Number 12/50416-6R.

The project was approved by the Medical Research Ethics Com- 
mittee of the University Hospital. The authors were exempt from requesting a free written informed consent term, since this is a retrospective study. Number and date of approval: 1082/2011;02/13/2012.

\section{Authors' contributions}

Brandalise NA: project conception, design; data acquisition, analysis, interpretation; drafting of the article; critical revision. Meirelles LR: pathology supervision, immunohistochemistry, slide review for eosinophil counts, critical revision. Servidoni MFPC: patient recruitment, data acquisition (endoscopy); critical revision. Cardoso SR: data acquisition (endoscopy); critical revision. Lomazi EA: data interpretation; critical revision.

Lomazi EA, Brandalise NA, Servidoni MFPC, Cardoso SR, Meirelles LR. Mastócitos discriminam esofagite eosinofílica em pacientes pediátricos. Arq Gastroenterol. 2017;54(3):192-6.

RESUMO - Contexto - Os mastócitos detêm papel fundamental na resposta imuno-alérgica gastrintestinal. Assim, é razoável admitir que essas células sejam úteis no diagnóstico diferencial das gastroenteropatias eosinofílicas. Objetivo - Determinar se a análise quantitativa de mastócitos na mucosa esofágica permite discernir esofagite eosinofílica, esofagite eosinofílica responsiva ao inibidor de bomba de prótons e esofagite péptica por doença de refluxo gastroesofágico. Métodos - Revisamos retrospectivamente os prontuários 53 crianças (idade: 7,8 anos; variação: 8-14 anos), atendidas consecutivamente, num serviço terciário e cujos diagnósticos definitivos estabelecidos após seguimento clínico foram esofagite eosinofílica ( $\mathrm{N}=23)$, esofagite eosinofílica responsiva ao inibidor de bomba de prótons $(\mathrm{N}=15)$ e esofagite péptica por doença de refluxo gastroesofágico $(\mathrm{N}=15)$. As amostras histológicas foram revisadas quanto à contagem de eosinófilos na coloração de H-E e processadas para imunoistoquímica da triptase de mastócitos. Resultados - Valores de eosinófilos/campo de maior aumento (CMA; 400X) >15 foram encontrados em 14 dos 15 pacientes com refluxo gastroesofágico. A média de eosinófilos/ CMA foi similar nos pacientes com esofagite eosinofílica e com esofagite eosinofílica responsiva ao inibidor de bomba de prótons, respectivamente, 42 e 39 eosinófilos/CMA, $P=0,47)$. Os valores de mastócitos triptase $(+)$ foram superiores no epitélio esofágico dos pacientes com esofagite eosinofílica [mediana: 25 mastócitos/CMA; variação (17-43)] e na esofagite eosinofílica responsiva ao inibidor de bomba de prótons [25 (16-32)], comparados aos pacientes com refluxo gastroesofágico [4(2-14)], $P<0,001$. Não houve diferença entre a média de mastócitos/CMA nos pacientes com esofagite eosinofílica comparados aos com esofagite eosinofílica responsiva ao inibidor de bomba de prótons, respectivamente, 26 e 24 mastócitos/CMA, $P=0,391$. Conclusão - A coloração para mastócitos pela imunoistoquímica da triptase diferencia as esofagites eosinofílicas da esofagite péptica.

DESCRITORES - Doenças do esôfago. Esofagite eosinofílica. Esofagite péptica. Mastócitos. Imuno-histoquímica.

\section{REFERENCES}

1. Blanchard C, Wang N, Stringer KF, Mishra A, Fulkerson PC, Abonia JP, al. Eotaxin-3 and a uniquely conserved gene-expression profile in eosinophilic esophagitis. J Clin Invest. 2006;116:536-47.

2. Dellon ES, Gonsalves N, Hirano I, Furuta GT, Liacouras CA, Katzka DA. ACG clinical guideline: evidenced based approach to the diagnosis and management of esophageal eosinophilia and eosinophilic esophagitis (EoE). Am J Gastroenterol. 2013;108:679-92.

3. Dranove JE, Horn DS, Davis, MA, Kernek KM, Gupta SK. Predictors of response to proton pump inhibitor therapy among children with significant esophageal eosinophilia. J Pediatr. 2009;154:96-100.

4. Evan S, Dellon ES, Speck O, Woodward K, Covey S, Rusin S, Gebhart JH, et al. Markers of eosinophilic inflammation for diagnosis of eosinophilic esophagitis and proton pump inhibitor-responsive esophageal eosinophilia: a prospective study. Clin Gastroenterol Hepatol. 2014;12:2015-22.

5. Francis DL, Foxx-Orenstein A, Arora AS, Smyrk TC, Jensen K, Nord SL, et al. Results of ambulatory $\mathrm{pH}$ monitoring do not reliably predict response to therapy in patients with eosinophilic oesophagitis. Aliment Pharmacol Ther 2012:35:300-7.

6. Ferreira CT, Vieira MC, Vieira SM, Silva GS, Yamamoto DR, Silveira TR [Eosinophilic esophagitis in 29 pediatric patients]. Arq. Gastroenterol. São Paulo, 2008;45:141-46.

7. Gonsalves N, Policarpio-Nicolas M, Zhang Q, Rao S, Hirano I. Histopathologic variability and endoscopic correlates in adults with eosinophilic esophagitis. Gastrointest Endoscopy. 2006;64:313-9.

8. Gupta SK, Fitzgerald JF, Kondratyuk T, HogenEsch H. Cytokine expression in normal and inflamed esophageal mucosa: a study into the pathogenesis of allergic eosinophilic esophagitis. J Pediatr Gastroenterol Nutr. 2006;42:22-6.

9. Katelaris $\mathrm{CH}$. Ocular allergy: implications for the clinical immunologist. Ann Allergy Asthma Immunol. 2003;90(6 Suppl 3):23-7.

10. Kirsch R, Bokhary R, Marcon MA, Cutz E. Activated mucosal mast cells differentiate eosinophilic (allergic) esophagitis from gastroesophageal reflux disease. J Pediatr Gastroenterol Nutr. 2007;44:20-6.

11. Kraneveld AD, Sagar S, Garssen J, Folkerts G. The two faces of mast cells in food allergy and allergic asthma: the possible concept of Yin Yang. Biochim Biophys Acta. 2012;1822:93-9.

12. Koda YK, Ozaki Mj, Murasca K, Vidolin E. Clinical features and prevalence of gastroesophageal reflux disease in infants at tending a pediatric gastroenterology reference service. Arq Gastroenterol. 2010;47:66-71.

13. Labenz J, Willmer C. Efficacy and safety of OTC omeprazole. MMW Fortschr Med. 2012;154 (Suppl 4):110-4.
14. Liacouras CA, Furuta GT, Hirano I, Atkins D, Attwood SE, Bonis PA, et al Eosinophilic esophagitis: Updated consensus recommendations for children and adults. J Allergy Clin Immunol. 2011;128:3-20.e6.

15. Lucendo AJ, Navarro M, Comas C, Pascual JM, Burgos E, Santamaría L, et al. Immunophenotypic characterization and quantification of the epithelial inflammatory infiltrate in eosinophilic esophagitis through stereology: an analysis of the cellular mechanisms of the disease and the immunologic capacity of the esophagus. Am J Surg Pathol. 2007;31:598-606.

16. Mueller S, Neureiter D, Aigner T, Stolte M. Comparison of histological parameters for the diagnosis of eosinophilic oesophagitis versus gastrooesophagea reflux disease on oesophageal biopsy material. Histopathology. 2008;53:676-84.

17. Ngo P, Furuta GT, Antonioli DA, Fox VL. Eosinophils in the esophagus - peptic or allergic eosinophilic esophagitis? Case series of three patients with esophagea eosinophilia. Am J Gastroenterol. 2006;101:1666-70.

18. Odze RD. Pathology of eosinophilic esophagitis: what the clinician needs to know. Am J Gastroenterol. 2009;104:485-90.

19. Protheroe C, Woodruff SA, de Petris G, Mukkada V, Ochkur SI, Janarthanan S, et al. A novel histologic scoring system to evaluate mucosal biopsies from patients with eosinophilic esophagitis. Clin Gastroenterol Hepatol. 2009;7:749-55.e11.

20. Rodrigo S, Abboud G, Oh D, DeMeester SR, Hagen J, Lipham J, et al. High intraepithelial eosinophil counts in esophageal squamous epithelium are not specific for eosinophilic esophagitis in adults. Am J Gastroenterol. 2008;103:435-42.

21. Rothenberg ME. Biology and treatment of eosinophilic esophagitis. Gastroenterology. 2009; 137:1238-49.

22. Rothenberg, ME. Molecular, genetic, and cellular bases for treating eosinophilic esophagitis. Gastroenterology. 2015;148:1143-57.

23. Sayej WN, Patel R, Baker RD, Tron E, Baker SS. Treatment with high-dose proton pump inhibitors helps distinguish eosinophilic esophagitis from noneosinophilic esophagitis. J Pediatr Gastroenterol Nutr. 2009;49:393-9.

24. Schroeder S, Capocelli KE, Masterson JC, Harris R, Protheroe C, Lee JJ, et al Effect of proton pump inhibitor on esophageal eosinophilia. J Pediatr Gastroenterol Nutr. 2013;56:166-72.

25. Soon IS, Butzner JD, Kaplan GG, deBruyn JC. Incidence and prevalence of eosinophilic esophagitis in children. J Pediatr Gastroenterol Nutr. 2013;57:72-80.

26. Sorser SA, Barawi M, Hagglund K, Almojaned M, Lyons H. Eosinophilic esophagitis in children and adolescents: epidemiology, clinical presentation and seasonal variation. J Gastroenterol. 2013;48:81-5.

27. Straumann A, Bauer M, Fischer B, Blaser K, Simon HU, Idiopathic eosinophilic esophagitis is associated with a $\mathrm{T}(\mathrm{H})$ 2-type allergic inflammatory response. $\mathrm{J}$ Allergy Clin Immunol. 2001;108:954-61.

28. Yamamoto E, Brito HSH, Ogata SK, Machado RS, Kawakami E. High rate of clinical and endoscopic relapse after healing of erosive peptic esophagitis in children and adolescents. J Pediatr Gastroenterol Nutr. 2014;59:594-9. 